る. 視覚に頼る場合の均一性フォトのプリセットカウン トは $999 \mathrm{~K} \times 3 \sim 999 \mathrm{~K} \times 4$ は必要である。

(2)輝点, 階調度のチェッタはRI階段ファントムて定 期的にスキャンすることにより，早く確实にチェックで きる.

\section{2. 当院に於ける RI 検查の現状}

大垣市民病院特殊放射線センター ○樋口亏马子・金森勇雄・本村得次 市川秀雄・鶴田初男・小野みき子

当院に於ける RI 検查の現状について報告した。 in vitro 部間に於ける 1ケ月間の検查検体数は, 51年の1300 検体が52年には 1,500 検体となり，乙れはほとんどの検 查項目による増加，及び，本年より加わったグルカゴン， セクレチン, IGERAST, $\mathrm{E}_{3}$ によるものである.

In Vivo 部閑於してす, 50 年の 60 件が, 51 年には 100件，52年には180件しなった。肝，脳，骨，軙，等の 増加と其に， ${ }^{99 \mathrm{~m}} \mathrm{Tc}$ の標識物による胆道シンチも施行さ れ， ${ }^{99 \mathrm{~m}} \mathrm{Tc}$ の使用量には注目に值するものを感しる。乙 の様に RI そよる検査は，今後堌々堌加し，診断上他の 検查法とも合わせ，次ととのできなり有用な検査とな るととを確認した。

\section{3. 七クレチンキット「第一」の使用経験}

大坦市民病院放射線科

○鶴田初男・金森勇雄・市川秀男

木村得次・樋口ちつ子・小野みき子

セクレチンの RIA は1968年Young 等により報告され たが問題む多く普及するに至らなかった。

今回第一ラジオイソトープ研究所より二抗体法によ るセクレチンキットが開発されたので基礎的検討を行っ た.

\section{(結果)}

1. セクレチン抗血清の力価は $\mathrm{B}_{0} / \mathrm{T} \%$ で平均 $29.7 \%$ で あった。 2. 感度は $10 \%$ fall で平均 $64 \mathrm{Pg} / \mathrm{ml}$ であった。

3. 交父，希橎，回収試験や精度，再現性もほぼ满足 される結果であった。 4. 健常者の早期空腹時血中セク レチン濃度は $\mathrm{MISD}=98.4 \pm 35.0 \mathrm{Pg} / \mathrm{ml}$ であった.（n =24） 5. 生体中の七タレテン濃度虫他のホルモンと密 接な関連を保ち刻々変化しており，今後動態の解明が期 待される。

\section{4. $\mathrm{E}_{3}$ (Oestriol)RIA キットの使用経験について}

大坦市民病院特殊放射線センター

○小野みき子・金森勇雄・木村得次 市川秀男・鶴田初男・樋口ちつ子

尿中エストロゲン：主に $\mathrm{E}_{3}$ の測定は胎児胎盤機能㭘
查に広く用いられているが，本キットは，血申 $\mathrm{E}_{3}$ 濃度 ¿24時間尿の $\mathrm{E}_{3}$ 值と高い相関があると言われている。 今回我々は， $\mathrm{E}_{3} \mathrm{RIA} \neq$ キ ニインキュベーション，第一インキュベーション温度等 を検討した結果を報告した。それぞれ変化は，あまりな く，相関関係及び，再現性も，実用性範囲内でのバラッ キ, キットにおける問題もなく，使用説明通りで良いと いう結論を得た。

このことから，患者に対する不快，検体の取り扱い上 の問題を考え合+，今後 $\mathrm{E}_{3}$ は RIR による測定法为，普 及するものと考える。

\section{5. トリオンルブ M-125 の検討}

浜松医療センタ一放射線科

○藤井忠一大大沢 保 - 延沢秀二

青野敏彦・山村信彰

宮崎医大

近藤隆司

(目的)

トリオソルブ M-125 キットル就して 基礎的検討を行 sto.

(検討項目)

(1)インキュベーション温度，時間条件

(2)水洗回数による影響，(3)再現性及びロット間変動

(4)血清試料量及び RI 試薬量による影響

(5)トリオソルブ值との相関，(6)他検査值との関係

(7)手技者の被曝量

(結果)

(1)トリオソルブとは $r=0.984$ と良く相関した.

(2)ロット間変動は $3 \%$ 以内であった.

(3)高濃度域血清に対しインキュベーション因子が作用 し易い傾向が認められた。

(4)血清量が従来の半量であり，指被裀の軽減を期待出 来るので有用な検查法であると思われる.

\section{BSPI-131 停滞率試験 (131IBSP による肝機能検查-2)}

忮皁书聖病院 谷口済男

131BSP による肝機能検查が広く汎用され肝胆道系の 障害を敏感に反映し肝臓検査の指標となる有用性につい て発表されている.今回経時的腹部スキャニングに利用 されている131BSP を用いBSP-131I 血中 停滞率試験の 注射液絶対量を作製して停滞率試験を 124 例とついて行 った。また從来ダイナポットラジオアイトープ研究所 により使用されていだBSPキットによる停滞率 試験と 比較検討し他の生化学検查も含好てその相関性を得たの 